\title{
Prospects of Using Steel Pistons in Transport Diesel Engines
}

\author{
Fedor I. Abramchuk', Andrey N. Avramenko ${ }^{2 *}$ \\ ${ }^{1}$ Department of Internal Combustion engine, Kharkov National Automobile and Higway University, \\ Yaroslava Mudrogo st, 25, Kharkov, 61002, Ukraine \\ 2 Department of Hydrogen Power Engineering, A.M. Pidhirnyi Institute for Mechanical Engineering Problems NAS of Ukraine, \\ 2/10 Pozharsky St., Kharkov, 61046, Ukraine \\ * Corresponding author, e-mail: an0100@ukr.net
}

Received: 27 April 2018, Accepted: 16 July 2018, Published online: 14 November 2019

\begin{abstract}
The results of comparative design research in the thermal stress and strain state of the piston in transport diesel engine $2 \mathrm{~F} 10.5 / 12$ are given for its rated power operation. The standard piston is made of an aluminium alloy, and the modernized one, of steel. Piston thermal profiling and indicator test results were used for identifying the mathematical models and refining the boundary conditions for mechanics and heat conduction problems. To ensure reliable heat rejection from the piston, the paper considered the case of oil jet cooling. This was taken into account when describing the boundary conditions of the heat conduction problem. The thin-wall steel piston with oil jet cooling was shown to function reliably under the study conditions. The temperature in the first compression ring groove does not exceed $200^{\circ} \mathrm{C}$, and the radial deformation of the piston crown is less than half of that of an aluminium alloy standard piston.
\end{abstract}

\section{Keywords}

thermal stressed state, strain, thin-wall steel piston, diesel engine

\section{Introduction}

Increasing the boosting level and placing more stringent requirements on fuel efficiency and toxicity of exhaust fumes in modern transport diesel engines calls for using new materials for combustion chamber parts.

Steel is one of the promising materials for making pistons. As compared to aluminium alloys, steel has a much smaller linear expansion coefficient. This is why the thermo-mechanical deformation of the piston, primarily, of its crown is significantly smaller. During service, this makes engine running reliable with minimal gaps in the piston-cylinder pair. This has a positive effect on improving fuel efficiency and reducing the toxicity of exhaust fumes. Steel also has a major advantage over aluminium alloys as regards strength and wear resistance, with a positive effect on the service life of such a piston and the engine as a whole.

The drawbacks of steel are low heat transfer coefficient (2.5-3 times less than that of aluminium alloys), high density and challenges involving the production process of shaping complex configuration parts.

Hence, research was focused to the following: finding ways of developing technologies for manufacturing diesel engine steel pistons, and design and experimental evaluation of the piston thermal stress and strain state. Refining piston design is a crucial and priority line in the advancement of modern engine building.

\section{Review of the literature}

Such companies as Mercedes and Caterpillar manufacture thin-wall steel pistons for transport diesel engines (Autocar Pro News Desk, 2015; MAHLE Performance, 2008). For instance, Mercedes manufactures steel pistons for the diesel engine Mercedes-Benz E-class (E350 BlueTEC), (Autocar Pro News Desk, 2015). Steel pistons help increase the boosting level, fuel efficiency, and reduce the toxicity level of exhaust fumes (Autocar Pro News Desk, 2015).

Using advanced numerical methods for investigating the processes of injection, carburation, combustion and formation of toxic components in the engine cylinder enables investigating the processes inside the diesel engine cylinder and work out recommendations to improve the engine's indicators with a high level of information content and validity (Cursente et al., 2008; Ranjbar et al., 2009; Perini et al., 2017; Dolak and Reitz 2011; Munnannur et al., 2006; Ra et al., 2006; Genzale et al., 2008). 
Many studies are engaged in modeling the thermal stress and strain state of a piston (Abramchuk and Avramenko, 2009; Agarwal and Varghese, 2006; Dallwoo et al., 2012; Rahmani et al., 2017; Barbieri et al., 2017; Zhao et al., 2014; Lu et al., 2017; Schreer et al., 2014; Finol and Robinson, 2006). To increase the accuracy and information content of modeling results, they recommend considering groups of parts to account for joint thermomechanical deformation. These studies suggest considering the piston jointly with the piston pin when investigating the thermal stress state of a piston. This enables describing the piston fastening scheme and modeling its operation conditions more adequately (Abramchuk and Avramenko, 2009).

The works of authors (Westerfield et al., 2016; Panayi et al., 2009; Panayi and Schock, 2006; Yang et al., 2001) investigate modern methods of optimizing the piston configuration (choosing an efficient skirt profile) to reduce friction forces and improve ICE performance. Choosing an efficient shape of piston rings also helps in achieving environmentally friendly indicators of an ICE (Stratmann, 2012).

An integrated approach to improving the economic and environmental indicators of a diesel engine by using new materials for making combustion chamber parts, new methods of organizing the motoring cycle and improving the diesel engine control system is a promising line of research.

\section{Research goal and tasks}

The objective of research was conducting a comparative design estimate of the thermal stress and strain state of transport diesel engine pistons made of aluminium alloy AL25 and steel 40CrNi.

The research comprised the following tasks:

- reviewing the literature on the use of modern materials for making a diesel engine piston, and the techniques of modeling the thermal stress state of a piston;

- conducting motor tests in investigating the thermal state of a piston made of aluminium alloy AL25 used in diesel engine 2 F 10.5/12 under rated power conditions (piston thermal profiling) and record the indicator diagrams (indicator tests);

- developing a set of boundary conditions for mechanics and heat conductance problems to model the thermal stress state of a piston;

- developing a unique design of a thin-wall steel piston for diesel engine 2 F 10.5/12;
- using the finite-element method, conduct a comparative design estimate of the thermal stress state of pistons made of aluminium alloy AL25 and steel $40 \mathrm{CrNi}$; and

- assessing the prospects of using thin-wall steel pistons in transport diesel engines, and draw conclusions and make recommendations.

\subsection{Basics engine parameter}

The basic research stages and results are as follows. The object of research is the thermal stress and strain state of a piston in diesel engine 2 F 10.5/12. An aluminium alloy standard piston has a mass of $735 \mathrm{~g}$.

The brief specifications of the engine are given in Table 1.

\subsection{Experimental investigation}

The engine has a semi-spherical combustion chamber in the piston displaced relative to the cylinder axis. The cooling system is an air one. The cylinder is made of cast iron, and the cylinder head is made of an aluminium alloy.

Motor tests were conducted on a test bench at the A.M. Pidhirnyi Institute for Mechanical Engineering Problems NAS of Ukraine.

Fig. 1 shows the drawing for modifying the aluminium alloy AL25 piston to install thermocouples.

\begin{tabular}{lc}
\multicolumn{2}{c}{ Table 1 Diesel technical characteristics } \\
\hline Parameter & Value \\
\hline S/D ratio, mm & $120 / 105$ \\
Compression degree & 16.5 \\
Rated power, $\mathrm{kW}$ & 18.4 \\
Maximum torque, $\mathrm{nM}$ & 102 \\
Rotational speed corresponding to & 1,800 \\
maximum power, min & \\
\hline
\end{tabular}

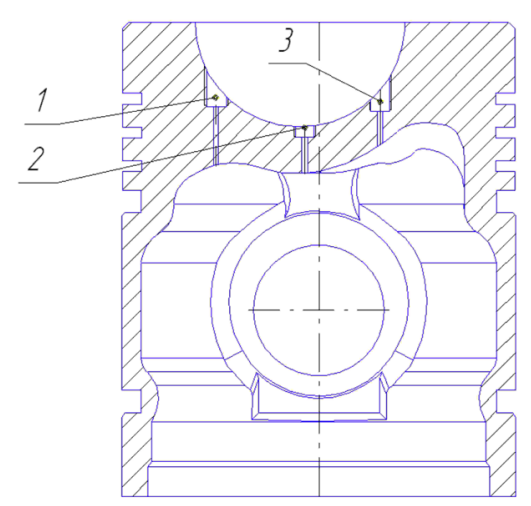

Fig. 1 Drawing for modifying the aluminium alloy AL25 piston to install thermocouples: 1-3 - thermocouples. 
Piston thermal profiling was conducted using chromel-alumel thermocouples with a junction bead diameter of $0.7 \mathrm{~mm}$. Threaded inserts were used to install the thermocouples in the piston body (Fig. 2). The signals from thermocouples were fed via a continuous current pickoff, a signal amplifier and an analog-to-digital converter (model E14-140) to a computer.

Indicator tests were conducted using a small-size strain gauge pressure transducer installed in the cylinder head. The transducer was linked to the engine combustion chamber via the indicator channel. Dedicated software by the Power Graph company was used for recording the signals from the thermocouples and pressure transducer.

Motor test results were used to build a set of boundary conditions (BC) for mechanics and heat conductance problems to model the piston thermal stress state. The set of $\mathrm{BC}$ of the third kind was built using the results of piston thermal profiling, indicator tests and method to calculate the average total heat transfer coefficient in the diesel engine combustion chamber (Finol and Robinson, 2006).

Next, with account of the studies by Mercedes and Caterpillar (Autocar Pro News Desk, 2015; MAHLE Performance, 2008), a unique design of a thin-wall steel piston for diesel engine $2 \mathrm{~F}$ 10.5/12 was developed. The thickness of the piston walls (especially the skirt) was chosen with account of its manufacturability, for instance, the volume forging method, and constraints imposed on piston strength and mass. Follow-up research will consider the contact problem (piston, piston pin, the small end and cylinder sleeve) to choose an efficient profile of the steel piston side surface by using advanced optimization methods (Westerfield et al., 2016; Panayi et al., 2009; Panayi and Schock, 2006; Yang et al., 2001).

The general view of the standard and thin-wall steel pistons for diesel engine $2 \mathrm{~F}$ 10.5/12 is shown in Fig. 3.

\subsection{Numerical simulation}

The height of the thin-wall steel piston is $110 \mathrm{~mm}$, the skirt height was reduced, and the number of oil control rings was reduced from 2 to 1 . The piston wall thickness near the skirt was reduced from 6 to $2.5 \mathrm{~mm}$; the thickness of the combustion chamber wall in the piston was reduced on the average from 7 to $3 \mathrm{~mm}$; the thickness of the wall for the piston pin bore was reduced from 6 to $2.5 \mathrm{~mm}$. These measures made it possible to develop a design of a thin-wall steel piston with a mass of $735 \mathrm{~g}$, identical to that of a standard aluminium alloy piston.
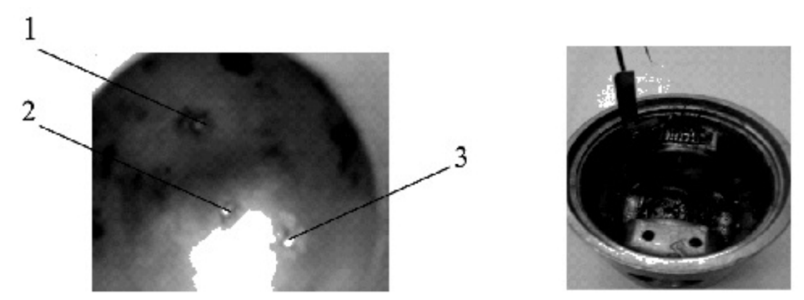

Fig. 2 Installing thermocouples in the piston (continuous current pickoff): $1-3$ - thermocouples

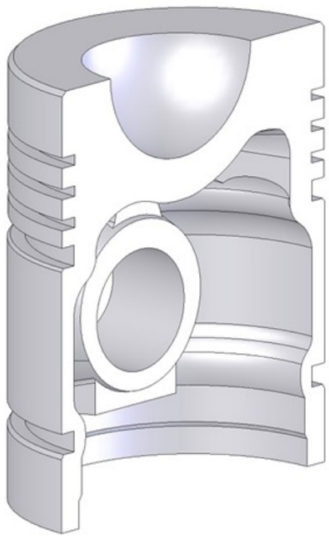

(a)

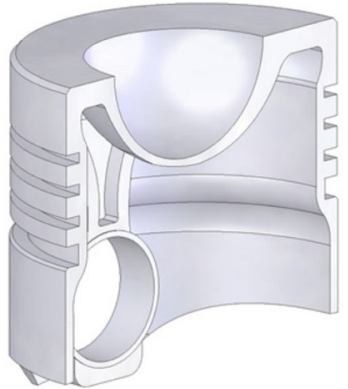

(b)
Fig. 3 Design of the standard and thin-wall steel pistons: (a) standard aluminium alloy AL25 piston; (b) thin-wall steel 40CrNi piston

The finite element method was used for a comparative design estimate of the thermal stress state of pistons made of aluminium alloy AL25 and steel 40CrNi. Fig. 4 shows the scheme of assignment of $\mathrm{BC}$ of the third kind. Table 2 shows the boundary condition values for the standard and thin-wall steel pistons.

With account of the recommendations of studies (Abramchuk and Avramenko, 2009), 19 zones were identified on the heat exchange surface of the piston where the $\mathrm{BC}$ were assigned for the heat transfer problem. The piston fastening scheme was chosen with account of studies (Abramchuk and Avramenko, 2009). When describing the mechanics problem, the load was taken to be the maximum cylinder combustion pressure $P_{z}=7.84 \mathrm{MPa}$ registered during the motor experiment at a rated power of $N e=18.4 \mathrm{~kW}$ and $n=1,800 \mathrm{~min}^{-1}$.

In the paper presented, the load diagram was considered for the static piston position in the TDC. Since it was possible to make the steel piston mass equal to that of a standard aluminium alloy one, the inertia forces thrust for aluminium alloy and steel pistons was virtually identical. To increase numerical simulation accuracy with 


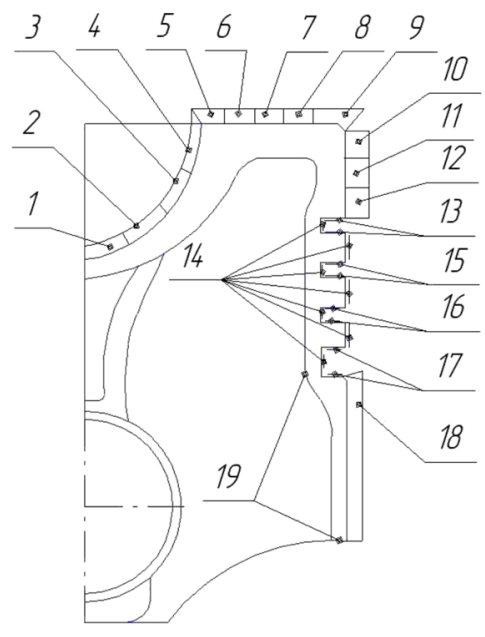

Fig. 4 Assignment of $\mathrm{BC}$ of the third kind

\begin{tabular}{|c|c|c|c|c|}
\hline \multirow{3}{*}{ № Zone } & \multicolumn{2}{|c|}{ AL25 } & \multicolumn{2}{|c|}{$40 \mathrm{CrNi}$} \\
\hline & \multicolumn{2}{|c|}{$\mathrm{BC}$ values } & \multicolumn{2}{|c|}{$\mathrm{BC}$ values } \\
\hline & $a, \mathrm{Wt} /\left(\mathrm{m}^{2 \circ} \mathrm{C}\right)$ & $\mathrm{t},{ }^{\circ} \mathrm{C}$ & $a, \mathrm{Wt} /\left(\mathrm{m}^{2}{ }^{\circ} \mathrm{C}\right)$ & $t,{ }^{\circ} \mathrm{C}$ \\
\hline 1 & 320 & 950 & 300 & 945 \\
\hline 2 & 350 & 950 & 350 & 950 \\
\hline 3 & 400 & 950 & 400 & 950 \\
\hline 4 & 450 & 950 & 450 & 950 \\
\hline 5 & 450 & 950 & 460 & 950 \\
\hline 6 & 400 & 960 & 400 & 950 \\
\hline 7 & 330 & 950 & 330 & 980 \\
\hline 8 & 290 & 800 & 290 & 800 \\
\hline 9 & 260 & 800 & 260 & 810 \\
\hline 10 & 270 & 550 & 250 & 580 \\
\hline 11 & 200 & 500 & 200 & 500 \\
\hline 12 & 200 & 450 & 200 & 450 \\
\hline 13 & 16000 & 220 & 16000 & 220 \\
\hline 14 & 200 & 250 & 200 & 250 \\
\hline 15 & 11000 & 190 & 11000 & 190 \\
\hline 16 & 6000 & 175 & 6000 & 170 \\
\hline 17 & 3000 & 140 & 3200 & 150 \\
\hline 18 & 500 & 120 & 500 & 120 \\
\hline 19 & 500 & 90 & $1600^{*}$ & $95^{*}$ \\
\hline
\end{tabular}

* - oil cooling

account of acceleration loads in follow-up research, the joint thermo-mechanical strain of a group of parts (piston, piston pin, the small end and the cylinder sleeve) will be considered.

Table 3 summarizes the thermophysical properties of aluminium alloy AL25 and steel $40 \mathrm{CrNi}$.

The temperature field of the standard and thin-wall steel pistons is shown in Fig. 5.
Table 3 Thermophysical properties of aluminium alloy AL25

\begin{tabular}{|c|c|c|c|c|}
\hline \multicolumn{5}{|c|}{ Material - AL25 } \\
\hline$t,{ }^{\circ} \mathrm{C}$ & 100 & 200 & 280 & 350 \\
\hline$\alpha \cdot 10^{6},{ }^{\circ} \mathrm{C}^{-1}$ & 20.2 & 22.7 & 24 & 25 \\
\hline$E, \mathrm{GPa}$ & 74.3 & 68.2 & 59 & 49 \\
\hline$v$ & \multicolumn{4}{|c|}{0.3} \\
\hline$\lambda,(\mathrm{W} / \mathrm{m} \cdot \mathrm{K})$ & 138 & 140 & 145 & 149 \\
\hline$\rho, \mathrm{kg} / \mathrm{m}^{3}$ & \multicolumn{4}{|c|}{2.8} \\
\hline$C p,(\mathrm{~kJ} / \mathrm{kg})$ & \multicolumn{4}{|c|}{0.896} \\
\hline \multicolumn{5}{|c|}{ Material - 40CrNi } \\
\hline$t,{ }^{\circ} \mathrm{C}$ & 100 & 200 & 300 & 400 \\
\hline$\alpha \cdot 10^{6},{ }^{\circ} \mathrm{C}^{-1}$ & 11.8 & 12.3 & 13.4 & 14.4 \\
\hline$E, \mathrm{GPa}$ & \multicolumn{4}{|c|}{200} \\
\hline$v$ & \multicolumn{4}{|c|}{0.3} \\
\hline$\lambda,(\mathrm{W} / \mathrm{m} \cdot \mathrm{K})$ & 44 & 43 & 41 & 39 \\
\hline$\rho, \mathrm{kg} / \mathrm{m}^{3}$ & 7.8 & 7.77 & 7.74 & 7.7 \\
\hline$C p,(\mathrm{~kJ} / \mathrm{kg})$ & 0.5 & 0.51 & 0.56 & 0.63 \\
\hline
\end{tabular}

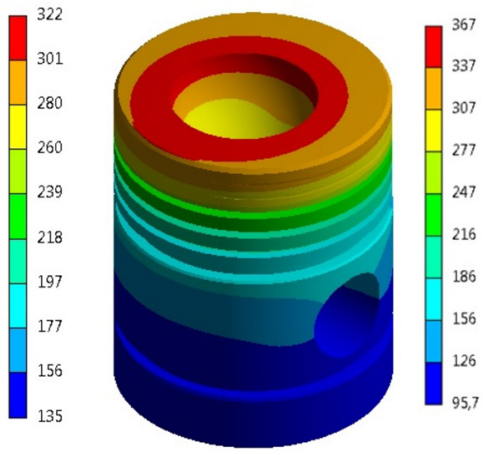

(a)

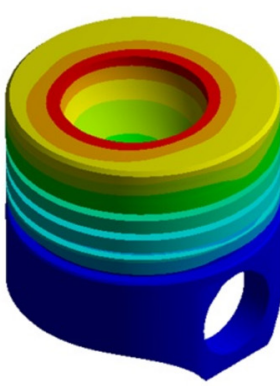

(b)
Fig. 5 Temperature field of the standard (a) and thin-wall (b) pistons

The maximum standard piston temperature reaches $322{ }^{\circ} \mathrm{C}$ in the zone of the combustion chamber edge in the piston (Fig. 5(a)). In the zone of the groove for the first compression ring, the piston temperature does not exceed $220^{\circ} \mathrm{C}$. The temperature over the piston skirt height drops from $180{ }^{\circ} \mathrm{C}$ to $135^{\circ} \mathrm{C}$.

The thin-wall steel piston shows a temperature increase to $367{ }^{\circ} \mathrm{C}$ in the zone of the combustion chamber edge in the piston (Fig. 5(b)), which is non-critical for steel $40 \mathrm{CrNi}$. The temperature rise is due to lower thermal conductivity of steel. In the zone of the groove for the first compression ring, the piston temperature does not exceed $205{ }^{\circ} \mathrm{C}$. The temperature over the piston skirt height drops from 180 to $95^{\circ} \mathrm{C}$. This is due to improved heat rejection from the piston by oil jet cooling of its inner surface. 
Fig. 6 shows the temperature and thermal elastic stress profiles for a standard piston in the meridional section perpendicular to the piston pin axis.

The temperature field over the piston height and radius is very irregular. The temperature in the zone of the combustion chamber edge in the piston reaches $320^{\circ} \mathrm{C}$ (Fig. 6(a)); in the zone of the piston edge it reaches $270^{\circ} \mathrm{C}$; in the zone of the first groove for the oil control ring it reaches $180^{\circ} \mathrm{C}$, and in the piston skirt zone it reaches $150{ }^{\circ} \mathrm{C}$. The data in the rectangles are the piston thermal profiling results. As the results show (Fig. 6(a)), good agreement of design and experimental data was achieved. This is indicative of the proper statement and solution of the heat conductance problem.

The temperature difference over the piston radius and height (Fig. 6(a)) yields stresses and strain with an adverse effect on the conditions of its operation and engine service life. Stress intensity, as a composite indicator, was chosen as a criterion for estimating the level of piston thermal elastic stress. The maximum design stress was 60 $\mathrm{MPa}$ in the zone of the combustion chamber in the piston (Fig. 6(b)). In the zone of the piston crown, the stress was roughly $30 \mathrm{MPa}$, and that in the skirt zone was 5-15 MPa.

Fig. 7 shows the temperature and thermal elastic stress profiles for a thin-wall steel piston in the meridional section perpendicular to the piston pin axis.

In a thin-wall steel piston, the temperature difference over the piston height is smaller than that for a standard aluminium alloy piston (Fig. 7(a)). This is due to improved heat rejection from the piston by oil jet cooling of its inner surface.

The stress in a thin-wall steel piston was $75 \mathrm{MPa}$ in the zone of the combustion chamber in the piston (Fig. 7(b)), which is non-critical for steel $40 \mathrm{CrNi}$.

The results of estimating the deformed state of a piston - ovalisation of the piston crown under the effect of a thermomechanical load are shown in Fig. 8.

For a standard piston, the maximum radial deformation of the piston crown reaches $0.45 \mathrm{~mm}$ in the plane perpendicular to the piston pin axis (Fig. 8(a)). This is due to smaller piston stiffness in this plane. An irregular circumferential deformation of the piston crown (ovalisation) is also evident. This is due to displacement of the combustion chamber in the piston and different piston stiffness in the planes along the piston pin axis and perpendicular to it.

For a thin-wall steel piston, the maximum radial deformation of the piston crown reaches $0.21 \mathrm{~mm}$ in the plane perpendicular to the piston pin axis (Fig. 8(b)). The

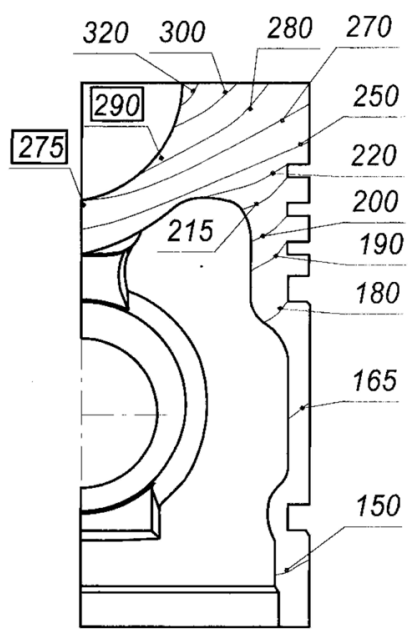

(a)

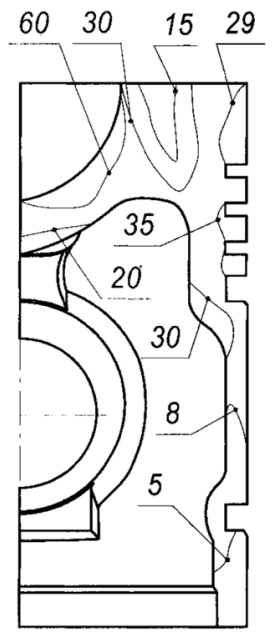

(b)
Fig. 6 Temperature (a), ${ }^{\circ} \mathrm{C}$ and thermal elastic stress (b), MPa profiles for a standard piston in the meridional section perpendicular to the piston pin axis

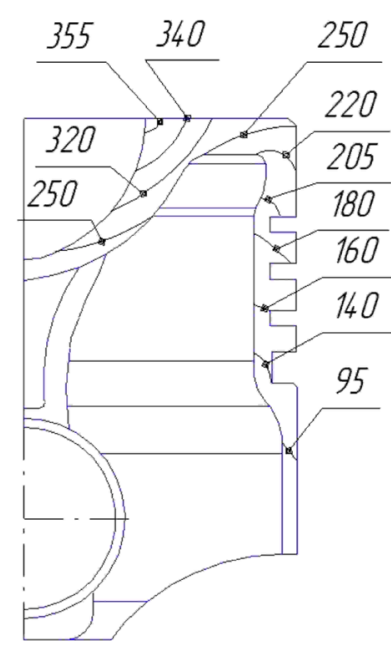

(a)

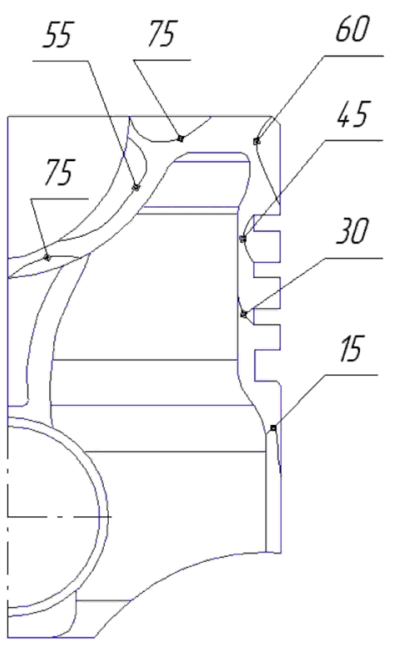

(b)
Fig. 7 Temperature (a), ${ }^{\circ} \mathrm{C}$ and thermal elastic stress (b), MPa profiles for a thin-wall steel piston in the meridional section perpendicular to the piston pin axis

smaller radial deformation of the thin-wall steel piston crown is due to bigger stiffness of the piston in the vertical direction and over the radius, and to a much smaller linear expansion coefficient of steel $40 \mathrm{CrNi}$ as compared to that of aluminium alloy AL25 (Table 3).

During service, bigger stiffness of the thin-wall steel piston in the vertical direction and over the radius will allow for a significantly smaller gap in the piston-cylinder and piston-piston rings pairs. This will reduce gas leakage to the engine crankcase, improve lubrication conditions, reduce friction losses, and have a positive effect on 


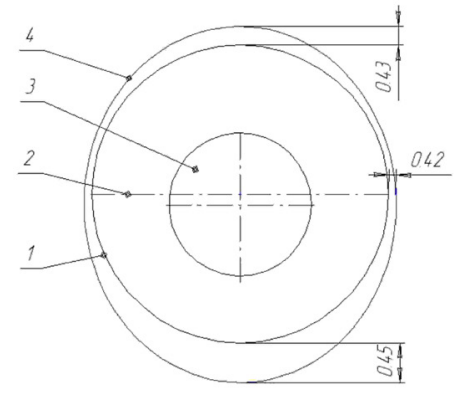

(a)

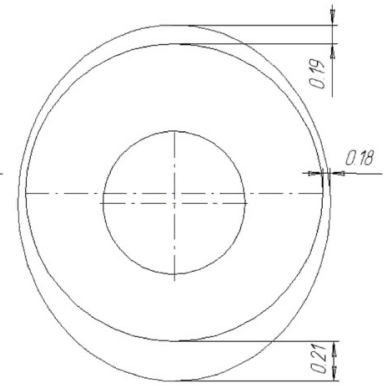

(b)
Fig. 8 Ovalisation of the piston crown under the effect of a thermomechanical load: 1- initial piston crown profile; 2 - piston pin axis; 3 - combustion chamber in the piston; 4 - deformed piston crown profile

improving fuel efficiency and reducing the toxicity of diesel engine exhaust fumes, along with improving piston operation conditions.

\section{Conclusions}

The research findings are as follows:

- For an air-cooled transport diesel engine 2 F 10.5/12, using a thin-wall steel piston under rated load running conditions reduces the radial deformation of the piston crown from $0.45 \mathrm{~mm}$ to $0.21 \mathrm{~mm}$.

- The temperatures and intensities of thermal elastic stresses in a thin-wall steel piston do not exceed admissible limits for the steel being used.

- Reducing the gaps in the piston-cylinder and piston-piston ring pairs will reduce the specific effective fuel consumption and toxicity of exhaust fumes during service.

\section{References}

Abramchuk, F., Avramenko. А. (2009) "Разработкаузловоймодели комплектапоршнябыстроходногодизеля" (Development of node model complete set of the piston high-speed diesel engine), Automobile Transport, 24, pp. 61-64. (in Russian)

Agarwal, A., Varghese, M. (2006) "Numerical investigations of piston cooling using oil jet in heavy duty diesel engines", International Journal of Engine Research, 7, pp. 411-421. https://doi.org/10.1243/14680874JER01804

Autocar Pro News Desk (2015) "Demand for steel pistons grows", [online] Available at: http://www.autocarpro.in/news-international/demand-steel-pistons-grows-8625 [Accessed: 27 July 2018]

Barbieri, S. G., Giacopini, M., Mangeruga, V., Mantovani, S. (2017) "A design strategy based on topology optimization techniques for an additive manufactured high performance engine piston", Procedia Manufacturing, 11, pp. 641-649.

https://doi.org/10.1016/j.promfg.2017.07.162
- Addressing issues related to using steel for making pistons for transport diesel engines is a promising line of further research.

- To increase the accuracy of estimating the thermal stress and strain state in a thin-wall steel piston, further research should model the process of interaction of the oil jet in the piston oil jet cooling system with the inner piston surface to refine the $\mathrm{BC}$ for the heat conductance problem.

\section{Acknowledgments}

The authors expresses his gratitude to Ph.D, Senior Research Fellow A. Levterov, Research Fellow V. Marakhovsky, Engineer N. Karasichenko, and the A.M. Pidhirnyi Institute for Mechanical Engineering Problems NAS of Ukraine for their assistance in preparing and conducting the motor experiment.

$\begin{array}{cl}\text { Notation } & \\ F & \text { four-stroke cycle } \\ D & \text { cylinder diameter }(\mathrm{mm}) \\ S & \text { piston stroke }(\mathrm{mm}) \\ P_{z} & \text { maximum combustion pressure }(\mathrm{MPa}) \\ \alpha & \text { material linear expansion coefficient }\left({ }^{\circ} \mathrm{C}^{-1}\right) \\ E & \text { Young's modulus }(\mathrm{GPa}) \\ u & \text { Poisson's ratio } \\ \lambda & \text { material thermal conductivity }(\mathrm{W} / \mathrm{mK}) \\ \rho & \text { material density } \\ C p & \text { material specific heat capacity }(\mathrm{kJ} / \mathrm{kg})\end{array}$

Cursente, V., Pacaud. P., Gatellier, B. (2008) "Reduction of the compression ratio on a HSDI diesel engine: combustion design evolution for compliance the future emission standards", SAE International Journalof Fuels and Lubrications, 1(1), pp. 420-439. https://doi.org/10.4271/2008-01-0839

Dallwoo, K., Akemi, I., Yasuhiro, I., Katsuyuki, O., Yoshiyuki, I. (2012) "Friction Characteristics of Steel Pistons for Diesel Engines", Journal of Materials Research and Technology, 1(2), pp. 96-10. https://doi.org/10.1016/S2238-7854(12)70018-2

Dolak, J., Reitz, R. (2011) "Optimization of the piston geometry of a diesel engine using a two-spray-angle nozzle", Proceedings of the Institution of Mechanical Engineers, Part D: Journal of Automobile Engineering, 225(3), pp. 406-421. https://doi.org/10.1177/09544070JAUTO1626 
Finol, C. A., Robinson, K. (2006) "Thermal modelling of modern engines: A review of empirical correlations to estimate the in-cylinder heat transfer coefficient", Proceedings of the Institution of Mechanical Engineers, Part D: Journal of Automobile Engineering, 220(12), pp. $1765-1781$.

https://doi.org/10.1243/09544070JAUTO202

Genzale, C., Reitz, R., Musculus, M. (2008) "Effects of Piston Bowl Geometry on Mixture Development and Late-Injection LowTemperature Combustion in a Heavy-Duty Diesel Engine", SAE paper, Number 2008-01-1330, Special Publication, SP-2185, Compression Ignition Combustion Processes, SAE International Journal of Engines, 1(1), pp. 913-937.

Lu, Y., Zhang, X., Xiang, P., Dong, D. (2017) "Analysis of Thermal Temperature Fields and Thermal Stress under Steady Temperature field of Diesel Engine Piston", Applied Thermal Engineering, 113, pp. $796-812$.

https://doi.org/10.1016/j.applthermaleng.2016.11.070

MAHLE Performance (2008) "World market leader for steel pistons for commercial vehicles", [online] Available at: https://www.mahle. com/en/news-and-press/press-releases/world-market-leader-forsteel-pistons-for-commercial-vehicles-473 [Accessed: 27 July 2018]

Munnannur, A., Abani, N., Reitz, R. (2006) "Use of a Pressure Reactive Piston to Control Diesel PCCI Operation - A Modeling Study", SAE Technical Paper, Number 2006-01-0921. https://doi.org/10.4271/2006-01-0921

Panayi, A. P., Diaz, A. R., Schock, H. J. (2009) "On the optimization of piston skirt profiles using a pseudo-adaptive response surface method", Structural and Multidisciplinary Optimization, 38(3), Article number: 317. https://doi.org/10.1007/s00158-008-0295-7

Panayi, A. P., Schock, H. J. (2006) "Piston Finite Element Modeling for the Estimation of Hydrodynamic and Contact Forces and Moments", In: ASME 2006 Internal Combustion Engine Division Fall Technical Conference, ASME Internal Combustion Engine Division Fall Technical Conference (ICEF2006), Sacramento, California, USA, pp. 457-473 https://doi.org/10.1115/ICEF2006-1587

Perini, F., Zha, K., Busch, S., Reitz, R. (2017) "Comparison of Linear, Non-Linear and Generalized RNG-Based k-epsilon Models for Turbulent Diesel Engine Flows", SAE Technical Paper, Number 2017-01-0561.

https://doi.org/10.4271/2017-01-0561
Ra, Y., Reitz, R., Jarrett, M., Shyu, T. (2006) "Effect of Piston Crevice Flows and Lubricant Oil Vaporization on Diesel Engine Deposits", SAE Paper, Number 2006-01-1149. https://doi.org/10.4271/2006-01-1149

Rahmani, R., Rahnejat, H., Fitzsimons, B., Dowson, D. (2017) "The effect of cylinder liner operating temperature on frictional loss and engine emissions in piston ring conjunction", Applied Energy, 191, pp. 568-581 https://doi.org/10.1016/j.apenergy.2017.01.098

Ranjbar, A., Sedighi, K., Farhadi, M., Pourfallah, M. (2009) "Computational study of the effect of different injection angle on heavy duty diesel engine", Thermal Science, 13(3), pp. 9-21. https://doi.org/10.2298/TSCI0903009R

Schreer, K., Roth, I., Schneider, S., Ehnis, H. (2014) "Analysis of Aluminum and Steel Pistons - Comparison of Friction, Piston Temperature, and Combustion", Journal of Engineering for Gas Turbines Power, 136(10), article ID: 101506-101506-7. https://doi.org/10.1115/1.4027275

Stratmann, J. (2017) "MAHLE Group Annual Report", MAHLE Group, Stuttgart, Germany, Rep. 20. [online] Available at: https://www. mahle.com/media/global/investor-relations/annual-reports/2017/ mahle_gb2017_en_gesamt.pdf [Accessed: 27 July 2018]

Westerfield, Z., Totaro, P., Kim, D., Tian, T. (2016) "An Experimental Study of Piston Skirt Roughness and Profiles on Piston Friction Using the Floating Liner Engine", SAE Technical Paper, Number 2016-01-1043.

https://doi.org/10.4271/2016-01-1043

Yang, J., Yang, W., Yu, X., Wang, C. (2001) "Design of Internal Combustion Engine Piston Based on Skirt Lubrication Analysis", SAE Technical Papers, Number 2001-01-2486. https://doi.org/10.4271/2001-01-2486

Zhao, J., F. Du, W. Yao. (2014) "Structural analysis and topology optimization of a bent-bar-frame piston based on the variable density approach", In: ASME 2014 Dynamic Systems and Control Conference, San Antonio, Texas, USA, pp. V002T30A002. https://doi.org/10.1115/DSCC2014-6118 